\title{
IV. ERRATUM
}

Bulletin géodésique no 51, 1936.

P. 337, ligne 24 : Le Comander G. B. Spicer Simson est Secrétaire général du Bureau hydrographique international et non Président du Comité de Direction de ce Bureau. Le Président est le Rear-Admiral J. D. Nares. 